\title{
Influence of socioeconomic factors on the perception of cochlear-vestibular symptoms and adherence to the treatment of congenital hypothyroidism
}

Gabriela Carvalho Machado 1

https://orcid.org/0000-0002-8737-1853

Caio Leônidas Oliveira Andrade 2

https://orcid.org/0000-0001-5103-6781

Ingrid Sampaio Souza 3

https://orcid.org/0000-0002-2241-1594

Luan Paulo Franco Magalhães 4

D https://orcid.org/0000-0001-8117-4245

Luciene da Cruz Fernandes 5

https://orcid.org/0000-0001-9744-1432

1-5 Universidade Federal da Bahia. Instituto de Ciências da Saúde. Av. Reitor Miguel Calmon s/n. Salvador, BA, Brasil. CEP: 40110-060. E-mail: gcarvalho.fono@yahoo.com.br

\begin{abstract}
Objectives: to verify if there is an association between socioeconomic factors and adherence to treatment in congenital hypothyroidism and to verify if there is an association between socioeconomic factors and vestibulocochlear symptoms noticed by parents/caregivers of children diagnosed with congenital hypothyroidism.

Methods: a cross-sectional, exploratory and descriptive study, with a convenience sample. The sample consisted of 108 children with clinical and laboratory diagnosis of congenital hypothyroidism, of both sexes, aged $\geq 5$ years. The researchers applied a structured questionnaire to parents/caregivers, consisting of closed and objective questions about the presence or absence of tinnitus, hearing loss and dizziness/vertigo in children with congenital hypothyroidism.

Results: There was no association between socioeconomic factors and adherence to treatment or perception of cochlear-vestibular symptoms.

Conclusions: socioeconomic factors did not influence treatment adherence or perceived cochlear-vestibular symptoms by caregivers of children with congenital hypothyroidism.

Key words Congenital hypothyroidism, Social class, Dizziness, Hearing loss, Tinnitus
\end{abstract}




\section{Introduction}

Congenital hypothyroidism $(\mathrm{CH})$ occurs when there is a reduction of production of thyroid hormones (THs). They function as regulators of metabolism 1 and are essential for the development of the central nervous system. ${ }^{2} \mathrm{CH}$ has an incidence of 1: 3,000 to 4,000 live births worldwide ${ }^{3}$ and is the most common cause of preventable intellectual disability. ${ }^{4}$ In Brazil, the incidence of $\mathrm{CH}$ is appro-ximately 1 : 2500 live births. ${ }^{5}$ In the State of Bahia, where the present study has been conducted, the incidence is 1 : 4,000 live births. ${ }^{6}$

The patients should start the treatment as early as possible by using hormone replacement with levothyroxine sodium (LT-4), ideally before 14 days of life. 7

Treatment adherence is essential for therapeutic success, since $\mathrm{CH}$ is a chronic disease that requires the continuous use of LT- 4 without time intervals or interruptions. When the treatment is not properly treated, it can cause motor, cognitive and sensorial impairment. 8

Adherence to a given treatment occurs when an individual takes at least $80 \%$ of the medication or follows the prescribed procedures, respecting the duration, times and doses indicated ${ }^{9}$

Therefore, social, cultural, financial and educational issues influence the use of medicines. Among the cultural issues, we accept the belief in the therapy's efficacy as the main one. 10 The economic issue is the main factor of non-adherence to a treatment, and the lower cost, the better adherence, as well as the prescribed amount of medication. ${ }^{11}$

The difficulties surrounding adherence to $\mathrm{CH}$ treatment have been a major challenge among physicians, since it is the main cause of the deregulation of the serum thyroid stimulating hormone (TSH) levels. 8

Scientists believe that the quality and adherence to $\mathrm{CH}$ treatment, as well as its long-term benefits, are associated with socioeconomic factors, being factors such as schooling, cultural level and family income that most influence therapeutic success. 12 However, there are other factors that may influence therapeutic adherence, such as the creation of a link between patient and therapist, language used, acceptance and mutual respect, ${ }^{9}$ as well as factors related to the perception and acceptance of the disease, health services, life, 13 and side effects of treatment. $9,14,15$

It is speculated that these factors related to hormonal follow-up may be intrinsically associated to the ability of the parents/caregivers of these chil- dren to cognize signs and symptoms of comorbidities, often correlated to $\mathrm{CH}$, such as auditory alterations and vestibular disorders.

THs are fundamental to the normal development of the auditory and vestibular system 16,17 and its deficiency is considered a risk factor for hearing loss. It is important to verify the perception of vestibulocochlear symptoms that may indicate alterations of these systems by parents/caregivers of children with $\mathrm{CH}$, with the purpose of helping in the early diagnosis of these alterations.

The present study aims to verify if there is an association between socioeconomic factors and adherence to treatment in $\mathrm{HC}$ and as a secondary objective, to verify if there is an association between socioeconomic factors and vestibulocochlear symptoms noticed by parents/caregivers of children diagnosed with $\mathrm{CH}$, in order to demonstrate the influence of these variables in the process of early detection of possible alterations to the auditory and vestibular system in this population.

\section{Methods}

This is a cross-sectional study, exploratory and descriptive, with convenience sampling. The sample consisted of 108 children with clinical and laboratory diagnosis of $\mathrm{CH}$, of both genders and aged $\geq 5$ years. The researchers followed up these children at a Neonatal Screening Referral Service from February to September 2015

The researchers excluded individuals with a middle and/or external ear disorder, risk factors for hearing loss according to the criteria described by the Joint Committee of Infant Hearing; 18 cognitive deficits or any other associated metabolic disorders.

To collect data, the researchers reviewed the medical records to investigate the current age/time of treatment of $\mathrm{CH}$, number of medical appointments performed, as well as socioeconomic characteristics of the individuals

To accomplish the economic classification of individuals, they based on the Brazilian Economic Classification Criterion (CCEB), whose methodology is to estimate the buying power of the urban families of the country. For each well-owned one is given a score and the total of it defines each class in A, B1, B2, C1, C2 and D-E. 19

Regarding cochlear-vestibular symptoms, they consulted the parents/caregivers of the children in order to investigate the presence of these factors in the sample studied. Accordingly, the researchers obtained information through the application of a structured questionnaire, 20 formed by closed and 
objective questions about the presence or absence of tinnitus, hearing loss and dizziness/vertigo in children with $\mathrm{CH}$.

Subsequently, the researchers tabulated the data in Excel software for Windows 8 and analyzed it by using the Statistical Package for Social Sciences (SPSS), version 20. They performed a descriptive analysis through average measurements, standard deviation, minimum and maximum values and absolute and relative frequencies. Finally, the researchers used the Chi-square test to verify the existence of a correlation between the variables: socioeconomic factors (level of schooling, profession, income and CCEB) and adherence to treatment with the perception of the cochlear-vestibular symptoms, for a significance level of $5 \%$ of $p \leq 0.05$.

The Committee of Ethics in Research with Human Beings through Opinion No. 534,704 approved the present research. All subjects had a Free and Informed Consent Form (TCLE) signed by their parents/caregivers and, when appropriate, signed the Informed Consent Form (TALE).

\section{Results}

The study included 108 children with $\mathrm{CH}$, most of them female $(57.4 \%)$, average age of 7.9 years and standard deviation of 3.0 days.

The researchers described the socioeconomic profile of caregivers of children with $\mathrm{CH}$ in Table 1, showing a higher concentration of individuals with incomplete elementary school level and informal work. In relation to income and CCEB, more than half of the individuals had income between $1 / 4$ to $1 / 2$ minimum wage and $>1$ to 2 minimum wages and economy class $\mathrm{C}$, respectively.

Concerning the perception of cochlear-vestibular symptoms reported by parents/caregivers of children with congenital hypothyroidism, the greatest perception was, among all, dizziness $(30.6 \%)$, followed by hypoacusis $(13.9 \%)$ and tinnitus $(12 \%)$. However, there was more lack of perception of cochlearvestibular symptoms in general, since $68.5 \%$ of the parents/caregivers of children with $\mathrm{CH}$ reported notnoticing dizziness, $81.5 \%$ did not notice hearing loss, and $85.2 \%$ reported not noticing tinnitus.

Children with $\mathrm{CH}$ had an average of 13.6 $(\mathrm{SD}=7.8)$ medical appointments and the average duration of the treatment was of $7.9(\mathrm{SD}=3.0)$ years. Therefore, there was no association between the treatment adherence variables and socioeconomic characteristics (Table 2). There was also no association between cochlear-vestibular symptoms (dizziness, tinnitus and hypoacusis) and socioeconomic factors (Table 3 ).

\section{Discussion}

One of the focuses of this study was to verify the existence of an association between socioeconomic factors and adherence to $\mathrm{CH}$ treatment, since $\mathrm{CH}$ is essential for therapeutic success. ${ }^{9}$ In addition to that, the adherence to treatment was associated with the level of schooling of caregivers, as the research states. Another study also evidenced the same, and it stated that the lower the level of schooling, the greater the chances of abandonment of treatment. ${ }^{21}$

Regardless of the level of education of the patient/caregiver, the issue of health education is important and should be the responsibility of the health team. This educational process must occur gradually and continuously, with the use of simple and adequate language at the socio-cultural level of individuals, respecting their individual characteristics. 22 These factors are decisive for good adherence, together with the relationship of trust established between the patient and the professionals involved in the treatment, demonstrations of respect and accomplishment of patient's reception. 9

A better understanding of the disease, the education received and the belief in the effectiveness of the therapy contribute to a better adherence to the treatment. 23 Thus, it is very important that the patients and caregivers have access to the information about the pathology in a clear way at the time of diagnosis, 24 even more in long-term treatments such as $\mathrm{CH}$, which are challenging when related to therapeutic adherence. 23

The Reference Service in Neonatal Screening (RSNS) performs a work aimed at clarifying the information about the $\mathrm{CH}$. In this service, the patients have regular appointments, besides receiving the appropriate medical attention. In addition, other professionals, who are part of the Neonatal Screening Program, such as nutritionist, psychologist, nurse, social worker, among others accompany the patient. They provide specialized care and perform activities to promote health by offering advice on the importance of correct hormonal follow-up for therapeutic success, for example.

In this way, it is suggested that in this study, the risks of low adherence to treatment related to issues of poor quality of information provided to caregivers of $\mathrm{CH}$ children participating in this research have been minimized.

However, the importance of the perception and acceptance of the disease, life's adversities and 
Table 1

Socioeconomic profile of caregivers.

\begin{tabular}{lcc}
\hline Socioeconomic characteristics & $\mathbf{N}$ & $\%$ \\
\hline Schooling & & \\
Never attended school & 04 & 3.7 \\
Elementary School Incomplete & 36 & 33.3 \\
Elementary School completed & 16 & 14.8 \\
High School Incomplete & 10 & 9.3 \\
High School Completed & 25 & 23.1 \\
Complete Higher Education Level & 06 & 5.6 \\
Incomplete Higher Education Level & 11 & 10.2 \\
Profession & & \\
Formal work & 51 & 47.2 \\
Informal work & 53 & 49.1 \\
Unemployed & 04 & 3.7 \\
Income & & 13.0 \\
$>1 / 2$ to 1 minimum salary & 14 & 6.5 \\
Up to $1 / 4$ minimum salary & 14 \\
$>1 / 4$ to $1 / 2$ minimum salary & 07 & 35.2 \\
$>1$ to 2 minimum salary & 38 & 31.5 \\
$>2$ to 3 minimum salaries & 34 & 1.9 \\
$>3$ minimum salaries & 02 & 11.1 \\
CCEB* & 12 & 1.8 \\
Class A & & 34.3 \\
Class B1-B2 & 02 & 54.6 \\
Class C1-C2 & 37 & 9.3 \\
Class D-E & 59 & \\
\hline
\end{tabular}

*CCEB= Critério de Classificação Econômica Brasil (Brazilian Economic Classification Criterion).

Table 2

Correlation between the variables adherence to treatment and schooling, profession, income and economic classification criterion Brazil.

\begin{tabular}{|c|c|c|c|c|}
\hline \multirow{3}{*}{ Adherence to treatment } & \multicolumn{4}{|c|}{ Socioeconomic characteristics } \\
\hline & Schooling & Profession & Income & CCEB ** \\
\hline & \multicolumn{4}{|c|}{$p^{*}$} \\
\hline Treatment time & 0.051 & 0.995 & 0.951 & 0.969 \\
\hline Number of appointments & 0.541 & 0.817 & 0.389 & 0.902 \\
\hline
\end{tabular}

p<0.05. *CCEB= Critério de Classificação Econômica Brasil (Brazilian Economic Classification Criterion). 
Correlation between the variables dizziness, tinnitus, hypoacusis and schooling, profession, income and economic classification criterion Brazil.

\begin{tabular}{lcccc}
\hline & \multicolumn{3}{c}{ Socioeconomic characteristics } \\
\cline { 2 - 5 } Cochleo-vestibular symptoms & Schooling & Profession & Income & CCEB* \\
\cline { 2 - 5 } & \multicolumn{3}{c}{$p$} \\
\hline Dizziness & 0.056 & 0.599 & 0.641 & 0.309 \\
Tinnitus & 0.888 & 0.922 & 0.521 & 0.497 \\
Hypoacusis & 0,498 & 0.830 & 0.900 & 0.821
\end{tabular}

p<0,05. *CCEB= Critério de Classificação Econômica Brasil (Brazilian Economic Classification Criterion).

issues related to support services are key factors for adherence, 13 as well as the existence of side effects of medications. $9,14,15$

On the other hand, some authors point out that the main factor of a low adherence to a treatment is economic-cultural,17 and the economic question leads the influence on therapeutic adherence.11 These findings are in contrast with the present study, since it did not show any association between profession, income, economic-social class and adherence to treatment.

In addition to the issues of adherence to $\mathrm{CH}$ treatment, the present study found that socioeconomic factors were not associated with the perception of cochlear-vestibular symptoms. However, the perception of these alterations may be associated with other factors related to the treatment, such as adherence, hormonal follow-up, etiology of the disease and its severity. 20 Thus, other questions may be involved in the greater or lesser perception of cochleo-vestibular symptoms other than socioeconomic ones.

There was little perception of these symptoms by caregivers of children with $\mathrm{CH}$. Among these, the most reported complaint was dizziness. Symptoms of dizziness are common, 25 with $85 \%$ of cases related to disorders of the vestibular system. 6 However, children tolerate them, and their complaints become evident when an instructed professional ask them properly. Generally, children who present these dysfunctions are restless, due to the need to find positions of comfort and safety. 25

It would be difficult for such characteristic and evident symptoms to go unnoticed by parents/caregivers, regardless of their level of education, which would also justify the fact that there is no association between socioeconomic factors and such symp- tomatology. Another factor that would also help in this perception would be the fact that $\mathrm{CH}$ is a chronic disease that requires care and accompaniment throughout life, as well as the fact that these children are accompanied by a Health Program that have shown positive results since its implementation, making parents/caretakers vigilant in their children's overall health.

However, it is worth mentioning that vestibular dysfunctions in childhood have the potential to affect communication skills and psychosocial status, as well as school performance, 27 which makes it essential to perform vestibular tests in children with vestibular symptoms. 28

The researchers observed a relative frequency $(13.9 \%)$ very close to the values of prevalence of hearing loss in individuals with $\mathrm{CH}$, which revolves around $20 \%$, when it comes to the symptoms related to the low auditory acuity reported by the caregivers. ${ }^{28}$ However, the presence of this auditory symptom does not necessarily mean the existence of hearing loss. The presence of hearing loss may be related to auditory processing disorder, as well as to subclinical auditory disorders. ${ }^{20}$

Therefore, in the presence of any symptoms related to low auditory acuity, it is necessary to perform diagnostic tests in order to discard peripheral auditory alterations, as well as to investigate dysfunctions in the central auditory system. The presence of hearing loss in childhood, even of a mild degree, causes delay in language and speech development, attention deficit, behavioral disorders and school problems. ${ }^{29,30}$

In view of the above, it is evident that several factors may be associated with the low adherence to a therapeutic treatment and the perception of otoneurological complaints. Thus, questions not raised by 
this study can be considered as limitations, and more detailed investigations are necessary to contemplate them. There was also a limitation of findings in the literature that pointed out questions associated with the perception of cochlear-vestibular symptoms.

The present study serves as an instrument to assist professionals directly involved in the care and health promotion of individuals with $\mathrm{CH}$, pointing out the need for a differentiated look at the aspects related to therapeutic adherence and to vestibulocochlear symptoms that may cause several deleterious effects.

The findings suggest that socioeconomic factors are not decisive for good adherence to treatment. However, other factors may influence it. When a structured health program, such as the Neonatal Screening Program, commits to their social function and guide their patients properly, adherence to therapy can be improved.

In conclusion, the perception of vestibulocochlear symptoms did not present any association with the socioeconomic factors of the parents/caregivers, given the intrinsic peculiarity of the dysfunctions that affect these systems, which have very evident and characteristic signs and symptoms.

\section{Contribution of the authors}

Machado GC, Andrade CLO, Souza IS - data collection and analysis, writing and revision of the final version. Magalhães LPF- data analysis, writing and revision of the final version. Fernandes LC- writing and review of the final version. All authors approved the final version of the manuscript.

\section{References}

1. Ramos HE, França SN, Maciel RMB. Novos aspectos da genética e dos mecanismos moleculares da morfogênese da tiróide para o entendimento da disgenesia tiroidiana. Arq Bras Endocrinol Metab. 2008; 52(9): 1403-15.

2. Haddow JE, Palomaki GE, Allan WC, Williams JR, Knight GJ, Gagnon J, O'Heir CE, Mitchell ML, Hermos RJ, Waisbren SE, Faix JD, Klein RZ. Maternal thyroid deficiency during pregnancy and subsequent neuropsychological development of the child. N Engl J Med. 1999; 341: 549-55.

3. American Academy of Pediatrics, Pediatric Endocrine Society. Congenital Hypothyroidism in Infants [Internet]. 2016 [acesso em 02 jul 2016]. Disponível em: https://www.healthychildren.org/English/health-issues/ conditions/Glands-GrowthDisorders/Pages/ Congenital-Hypothyroidism-Infants.aspx

4. Setian NS. Hypothyroidism in children: diagnosis and treatment. J Pediatr. 2007; 83 (Suppl. 5): S209-16.

5. Brasil. Ministério da Saúde. Programa Nacional de Triagem Neonatal (PNTN): Hipotireoidismo congênito (HC) [Internet]. 2017 [acesso em 25 fev 2018]. Disponível em: http://portalms.saude.gov.br/acoes-e-programas/programanacional-da-triagem-neonatal/hipotireoidismo-congenitohc

6. Almeida AM, Godinho TM, Teles MS, Rehem APP, Jalil HM, Fukuda TG, Araújo EP, Matos EC, Muritiba Júnior DC, Dias CPF, Pimentel HM, Fontes MIMM, Acosta AX Avaliação do Programa de Triagem Neonatal na Bahia no ano de 2003. Rev Bras Saúde Mater Infant. 2006; 6 (1): 8591.

7. Agrawal P, Philip R, Saran S, Gutch M, Razi MS, Agroiya P, Gupta K. Congenital Hypothyroidism. Indian J Endocrinol Metab. 2015; 19 (2): 221-7.

8. Gejão MG, Lamonica DAC. Habilidades do desenvolvimento em crianças com hipotireoidismo congênito: enfoque na comunicação. Pró-Fono R Atual Cient. 2008; 20 (1): 2530 .

9. Leite SN, Vasconcelos MPC. Adesão à terapêutica medicamentosa: elementos para a discussão de conceitos e pressupostos adotados na literatura. Ciênc Saúde Coletiva. 2003; 8 (3): 775-82

10. Kidd KE, Altman DG. Adherence in social context. Control Clin Trials. 2000; 21: 184S-7S.

11. Pessoa JHL, Balikjan P, Frittella S, Nascimento R, Ribeiro L. Não-adesão à prescrição após atendimento em prontosocorro pediátrico. Rev Paul Pediatr.1996; 14 (2): 73-7.

12. Rovet J, Walker W, Bliss B, Buchanan L, Ehrlich R. Longterm sequelae of hearing impairment in congenital hypothyroidism. J Pediatr. 1996; 128 (6): 776-83.

13. Faé AB, Oliveira EA, Silva LT, Cadê NV, Mezadri VA. Facilitadores e dificultadores da adesão ao tratamento da hipertensão arterial. Rev Enferm UERJ. 2006; 14 (1): 32-6.

14. Oigman W. Métodos de avaliação da adesão ao tratamento anti-hipertensivo. Rev Bras Hipertens. 2006; 13 (1): 30-4.

15. Cardoso GP, Angela A. As representações sociais da soropositividade e sua relação com a observância terapêutica. Ciênc Saúde Coletiva. 2004; 10: 151-62.

16. Fisher DA, Dussault JH, Foley JP, Klein AH, LaFranchi S, Larsen PR, Mitchell ML, Murphey WH, Walfish PG. Screening for congenital hypothyroidism: results of screening one million North American infants. J Pediatr. 1979; 94 (5): 700-5.

17. Bagattoli RM, Vaisman M, Lima JS, Ward LS. Adesão ao tratamento do hipotireoidismo. Arq Bras Endocrinol Metab. 2000; 44 (6): 483-7.

18. Joint Committe on Infant Hearing. Year 2007 Position Statement: Principles and Guidelines for Early Hearing Detection and Intervention Programs. Pediatrics. 2007; 120 (4): 898-921. 
19. ABEP (Associação Brasileira de Empresas de Pesquisa). Critério Brasil 2015 e atualização de distribuição de classes para 2016. 2016: 1-6.

20. Andrade CL, Machado GC, Fernandes LC, Braga H, BoaSorte N, Ramos HE, Alves C. Prevalência de sintomas otoneurológicos em indivíduos com hipotireoidismo congênito: estudo piloto. Cad Saúde Colet. 2017; 25 (2): 144-51.

21. Martins MRI, Cesarino CB. Qualidade de vida de pessoas com doença renal crônica em tratamento hemodialítico. Rev Latino-Am Enfermagem. 2005; 13 (5): 670-6.

22. Cazarini RP, Zanetti ML, Ribeiro KP, Pace AE, Foss MC Adesão a um grupo educativo de pessoas portadoras de diabetes mellitus: porcentagem e causas. Medicina. 2002; 35:142-50.

23. Schectman JM, Elinsky EG, Pawlson LG. Effect of education and feedback on thyroid function testing strategies of primary care clinicians. Arch Intern Med. 1991; 151 (11): 2163-6.

24. Oliveira FPS, Ferreira EAP. Adesão ao tratamento do hipotireoidismo congênito segundo relato de cuidadores. Psicol Reflex Crit. 2010; 23 (1): 19-28.

25. Formigoni LG. A avaliação vestibular na criança. In Ganança MM. Vertigem tem cura? São Paulo: Lemos; 1998. p. $117-26$

Received on July 23, 2018

Final version presented on March 18, 2019

Approved on April 24, 2019
26. Lourenço EA, Lopes KC, Pontes Jr A, Oliveira MH, Umemura A, Vargas AL. Distribuição dos achados otoneurológicos em pacientes com disfunção vestíbulo-coclear. Rev Bras Otorrinolaringol. 2005; 71 (3): 288-96.

27. Campos MI, Ganança FF, Caovilla HH, Ganança MM. Prevalência de sinais de disfunção vestibular em crianças com vertigem e/ou outros tipos de tontura. RBM-ORL. 1996; 3: $165-70$

28. Caovilla HH, Ganança MM, Munhoz MS, Silva ML, Ganança FF, Frazza MM. Vertigem paroxística benígna da infância. In: Silva ML, Munhoz MS, Ganança MM, Caovolla HH. Quadros clínicos otoneurológicos mais comuns. São Paulo: Atheneu; 2000. p.109-17.

29. Roslyn-Jensen AMA. Importância do diagnóstico precoce na deficiência auditiva. In: Ferreira LP. Tratado de fonoaudiologia. São Paulo: Roca; 1996. p.297-309.

30. Almeida K, Santos TMM. Seleção e adaptação de próteses auditivas em crianças. In: Almeida K, Iorio MCM. Próteses auditivas: fundamentos teóricos e aplicações clínicas. São Paulo: Lovise; 2003. p.357-80. 